\title{
PENERAPAN MEDIA GAMBAR DALAM PEMBELAJARAN BAHASA ARAB
}

\author{
Mega Primaningtyas \\ Sekolah Tinggi Agama Islam Masjid Syuhada Yogyakarta \\ megaprimaningtyas@hotmail.com
}

\begin{abstract}
Abstrak
Salah satu kegiatan terpenting dalam sebuah proses pembelajaran adalah cara penyampaian materi yang akan disampaikan. Sebuah materi tidak akan bernilai jika cara penyampaiannya tidak tepat. Cerita bergambar merupakan salah satu media yang dapat digunakan dalam penyampaian materi. Gambar terlihat lebih menarik visual dan lebih mengena dalam melatih fokus para pembelajar. Pembelajaran bahasa Arab menggunakan gambar dapat menjadi salah satu media yang membantu para pembelajar dalam memahami materi yang sedang dipelajari dengan menyenangkan.
\end{abstract}

Kata Kunci: Media, Cerita Bergambar, dan Pembelajaran Bahasa Arab

\section{Abstract}

One of the most important activities in a learning process is how to deliver the material to be delivered. A material Will not be valuable if its delivery is incorrect. Pictorial story is one of the media that can be used in the delivery of material. Images look more visually appealing and more engaging in training the learners' focus. Learning Arabic using pictures can be one of the media that helps learners in understanding the material being studied with fun.

Keywords: Media, Picture Stories, and Arabic Learning 


\section{A. Pendahuluan}

Bahasa Arab merupakan bahasa asing bagi masyarakat Indonesia. Seiring berjalannya waktu masyarakat mengenal bahasa Arab dengan sendirinya seiring kedatangan agama Islam ke Indonesia. Namun hal tersebut tidak menjadikan masyarakat Indonesia mampu menguasai bahasa Arab dengan sendirinya. Hal tersebut terjadi karena berbagai macam faktor yang melatar belakangi kemampuan berbahasa asing.

Salah satu fungsi pembelajaran bahasa Arab adalah terampil berbahasa dan mempunyai sikap positif terhadap bahasa Arab dengan pengembangan keterampilan berbahasa Arab yang terdiri dari empat keterampilan yaitu keterampilan menyimak, keterampilan berbicara, keterampilan membaca dan keterampilan menulis.

Materi bahasa Arab sudah dirancang sedemikian rupa agar mudah dipelajari. Namun ada idiom yang menyatakan Ath-Thoriqoh Ahammu Minal Maddah strategi pembelajaran itu lebih penting dari pada materi. Sebaik apapun materi yang akan disampaikan jika tidak memiliki strategi metode penyampaiannya maka materi tersebut akan sia-sia. Cara memberikan bahan pembelajaran akan mempengaruhi pemahaman dalam belajar. Semakin menarik dan bervariasi dalam menyampaikan materi, semakin tinggi prestasi belajar dan semakin banyak pula kreatifitas.

Cerita bergambar,komik, atau kartun merupakan buku 
yang cukup populer dimasyarakat khususnya pada kalangan remaja dan anak-anak,komik atau dengan istilah yang dikenal juga cerita bergambar (cergam) terdiri dari teks atau narasi yang berfungsi sebagai penjelasan dialog dan alur cerita.

Tulisan ini akan membahas bagaimana penerapan media cerita bergambar dalam pembelajaran bahasa arab dan seberapa penting penggunaan cerita bergambar dalam pembelajaran bahasa arab.

\section{B. Pembahasan}

\section{Media Gambar}

Al-Qasimi dan Assayyid mengelompokkan media pembelajaran menjadi empat. Pertama, berbagai jenis papan tayang untuk menayangkan materi tertentu. Papan tayang ini mencakup antara lain: (a) papan tulis dengan berbagai macam modelnya, (b) papan flanel, (c) papan saku, (d) papan pengumuman, (e) papan listrik, dan majalah dinding. Kedua, perangkat keras yang digunakan untuk menyajikan materi kepada siswa. Hal ini terdiri atas dua jenis: (a) perangkat audio, misalnya rekaman, radio, laboratorium bahasa, dan (b) perangkat visual, misalnya bahan tidak tembus pandang, bahan tembus pandang, slide, film strip, transparasi OHP, dan film gerak. Ketiga, berbagai jenis gambar, misalnya gambargambar yang diambil dari buku dan majalah, poster, dan peta. Keempat, benda tiga dimensi misalnya model, benda-benda 
yang terbuatdari plastik, dan sejenisnya. Kelima, programprogram pembelajaran interaktif berbasis komputer ${ }^{25}$.

Gambar merupakan media pembelajaran berbasis visual. Telah diketahui bahwa media berbasis visual seperti gambar dapat memudahkan pemahaman terhadap suatu materi pelajaran yang rumit atau kompleks. Media gambar dapat menyuguhkan elaborasi yang menarik tentang struktur atau organisasi suatu hal, sehingga juga memperkuat ingatan.

Media gambar dapat menumbuhkan minat siswa dan memperjelas hubungan antara isi materi pembelajaran dengan dunia nyata. Untuk memperoleh kemanfaatan yang sebesarbesarnya pada penggunaan media gambar dalam pembelajaran ini, maka ia haruslah dirancang dengan sebaik-baiknya.

Dibidang pengajaran bahasa asing Al-Qasimi (1980) mengemukakan pentingnya atau manfaat penggunaan media pembelajaran, yaitu untuk: 1) membatasi/ mengurangi penggunaan teknik terjemah, 2) memastikan bahwa siswa benar-benar memahami makna, (3) menambah kemenarikan dan kesenangan siswa terhadap pelajaran, dan (4) menjadi stimulus atau perangsangperan serta dan keterlibatan siswa.

Edgar Dale telah menggambarkan tingkat penyerapan informasi melalui berbagai pengalaman dalam bentuk kerucut yang terkenal dengan pengalaman Edgar Dale. Kerucut

25Imam asrori dan Moh Ahsanudin, Media pembelajaran bahasa Arab dari kartu sederhana sampai web penjelajah dunia, (Malang: Bintang Sejahtera: 2016), hlm.12

48 Jurnal Komunikasi dan Pendidikan Islam, Volume 1, Nomor 1, Juni 2018 
dibawah ini memberikan gambaran yang jelas bahwa pembelajaran yang sekedar menampilkan stimulus lisan menghasilkan gambar yang terbatas. Kadar pemahaman akan semakin besar jika dimunculkan stimulus yang lain, misalnya stimulus pandang, gerak bahkan sampai perlibatan siswa untuk memperoleh pengalaman, baik pengalaman buatan maupun pengalaman nyata. Luas sempitnya medan kerucut menggambarkan luasnya pemahaman atau hasil belajar yang diperoleh siswa ${ }^{26}$.

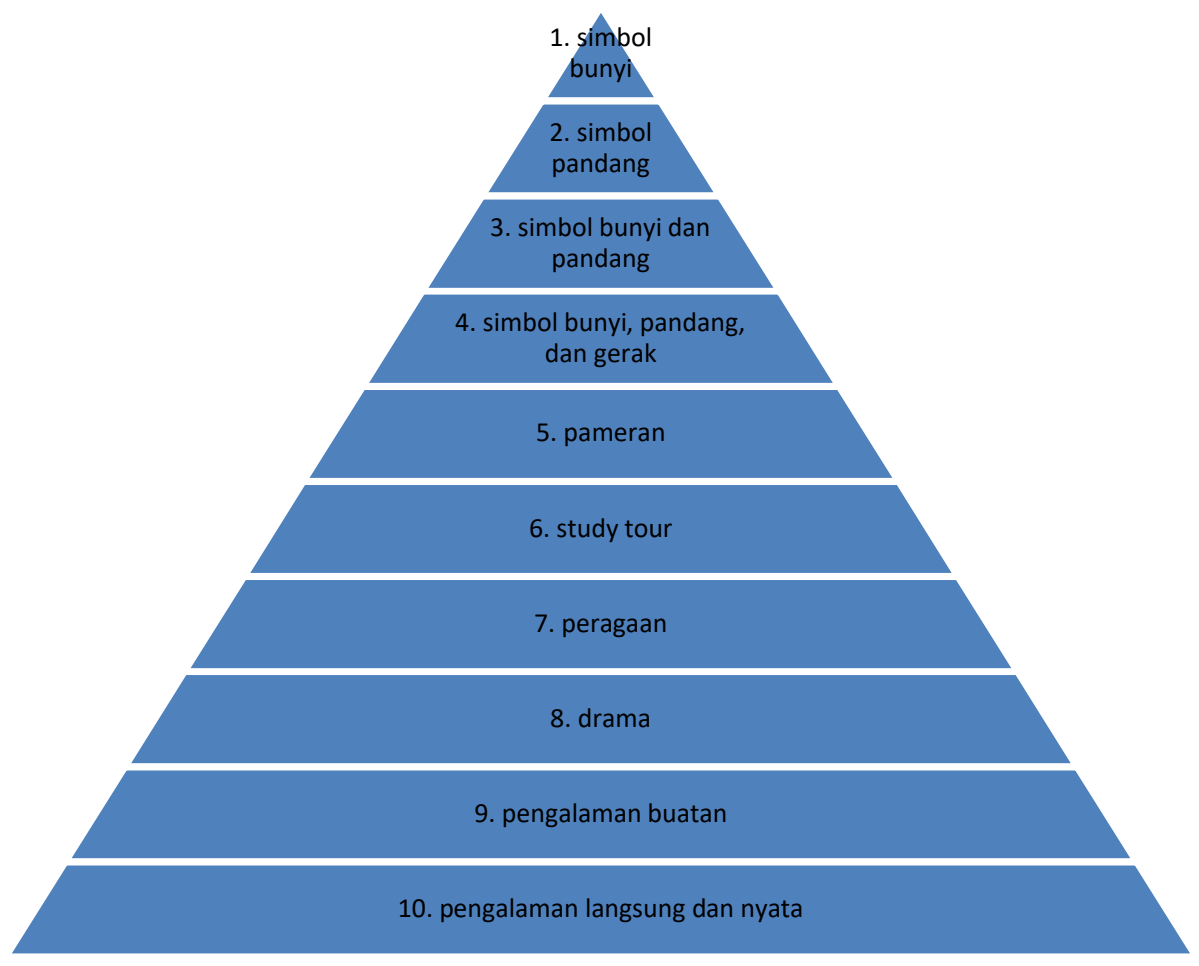

26Imam Asrori dan Moh. Ahsanuddin, Media Pembelajaran Bahasa Arab dari Kartu Sederhana sampai Web Penjelajah Dunia,(Malang: Bintang Sejahtera: 2016) hlm. 24 
Hal-halyang perlu diperhatikan dalam mengembangkan dan menggunakan media dalam memfasilitasi pembelajaran adalah $^{27}$ :

a. Media yang dikembangkan dan dipergunakan dalam fasilitasi tidak boleh terlalu bersifat memberi informasi dan tidak bersifat instruksional, tetapi lebih bersifat mengajukan permasalahan yang ada.

b. Penyajian media yang ada harus diikuti dengan fasilitasi dan pembahasan oleh para peserta dengan jalan menjawab atau menfasilitasikan berbagai pertanyaan yang diajukan oleh fasilitator, sesuai dengan siklus belajar berdasarkan pengalaman:

1) Mengalami

2) Mengungkapkan pengalaman

3) Analisis

4) Menarik kesimpulan

5) Menerapkan, yang akhirnya menimbulkan pengalaman baru

Nana Sudjana, mengatakan bahwa hasil penelitian Seth Spaulding tentang bagaimana pembelajar belajar melalui gambar, antara lain sebagai berikut ${ }^{28}$ :

${ }^{27}$ Menjembatani_penelitian_dan_kebijakan, akses 16 november 2017http://www.smeru.or.id/report/training//untuk_cso/file/3547.pdf.

${ }^{28}$ Nana Sudjana dan Ahmad Rivai, Media Pengajaran (penggunaanya dan pembuatannya), (Bandung: CV. Sinar Baru:1991), hlm 12.

50 Jurnal Komunikasi dan Pendidikan Islam, Volume 1, Nomor 1, Juni 2018 
a. Ilustrasi gambar merupakan perangkat pengajaran yang dapat menarik minat belajar pembelajar secara efektif, dalam booklet pada umumnya satu halaman penuh bergambar.

b. Ilustrasi gambar merupakan perangkat tingkat abstrak yang dapat ditafsirkan berdasarkan pengalaman di masa lalu, melalui penafsiran kata-kata.

c. Ilustrasi gambar isinya harus dikaitkan dengan kehidupan nyata, agar minat para pembelajar menjadi efektif.

d. Ilustrasi gambar isinya hendaknya ditata sedemikian rupa sehingga tidak bertentangan dengan gerakan mata pembelajar dan bagian yang paling penting dari ilustrasi tersebut.

Cerita bergambar sebagai karya visual memiliki dua unsur utama yakni unsur cerita dan unsur visual. Unsur visual terdiri dari ilustrasi dan teks. Ilustrasi merupakan gambar yang bermaksud untuk memperjelas sesuatu hal. Cerita bergambar tidak hanya sebagai media penghibur, tetapi pada saat ini juga berfungsi sebagai media pembelajaran. Cerita bergambar telah menjadi media yang mampu merubah penyampaian konsep yang bertele-tele menjadi mudah dan menyenangkan untuk dibaca. Bahasa yang digunakan pun sederhana, singkat, akan tetapi komunikatif ${ }^{29}$.

${ }^{29}$ karya-ilmiah.um.ac.id, akses 16 november 2017/index.php/pkm/index. 
Berdasarkan karakteristik media, para ahli mengklasifikasikan media antara lain ${ }^{30}$ :

a. Menurut Rudy Bretz bahwa media dapat dibagi menjadi tiga unsur pokok yaitu: suara, visual, dan gerak sehingga terdapat 8 klasifikasi media, media audio visual gerak, media audio visual diam, media visual semi gerak, media audio, media visual dan media cetak.

b. Menurut Briggs media dapat dibagi menjadi 13 macam yang digunakan dalam proses pembelajaran yaitu: obyek, model, suara langsung, rekaman audio, media cetak, pembelajaran terprogram, papan tulis, media transparansi, film rangkai, film bingkai, film televisi, dan gambar.

c. Menurut Gagne media dapat dikelompokkan ke dalam 7 macam yaitu: benda untuk didemonstrasikan, komunikasi lisan, media cetak, gambar diam, gambar gerak, film bersuara dan mesin belajar.

Cerita bergambar berbahasa Arab akan menuntut pembacanya mengenal kosa kata bahasa Arab. Kosa kata yang dikenalkan melalui bahasa cerita akan mudah dimengerti siswa dibanding dengan kosa kata yang terpenggal-penggal atau ditulis dalam bentuk non story. Hal itu dapat mempercepat siswa untuk menghafal kosakata dan memperkayanya. Dengan kekayaan kosa kata yang sesuai dengan kurikulum, cerita bergambar ini diharapkan mampu mendukung pembelajaran

${ }^{30}$ Arif Sadiman, R. Rahardjo, dkk, Media Pendidikan Pengertian Pengembangan dan Pemanfaatannya, (Jakarta: PT. Raja Grafindo: 1993) hlm. 20-23

52 Jurnal Komunikasi dan Pendidikan Islam, Volume 1, Nomor 1, Juni 2018 
bahasa Arab. Bagaimanapun memahami dan menghafal kosakata merupakan dasar untuk terampil berbahasa.

Cerita bergambar dapat diterapkan dalam beberapa kompetensi kebahasaan, yaitu membaca, gramatikal, menulis, dan menyimak. Pada kompetensi membaca, cerita bergambar membantu pembaca untuk lebih memahami alur cerita, dan mempermudah para pembaca dalam memahami isi bacaan, selain itu pembaca tidak akan merasa jenuh saat membaca, hal itu dikarekan adanya gambar-gambar yang ada dalam cerita. Pada kompetensi gramatikal, cerita bergambar juga membantu siswa, karena kaidah-kaidah bahasa yang dipelajari dapat langsung diterapkan dalam cerita bergambar. Pada kompetensi menulis, cerita bergambar dapat divariasikan dengan cara siswa yang membuat cerita sendiri yang sesuai dengan gambar yang tersedia. Hal ini akan melatih siswa dalam menggunakan bahasa arab, selain itu daya imajinasi siswa juga akan terasah. Pada kompetensi menyimak, siswa akan belajar berbagai macam emosi dalam membaca. Dengan mendengarkan intonasi membaca yang sesuai dengan alur cerita akan merangsang daya emosi, siswa pun akan memahami apakah para tokoh dalam cerita itu sedang susah, senang, sedih, gembira, dan lain sebagainya. Penerapan media cerita bergambar ini dapat diterapkan pada siswa yang telah mengetahui berbagai macam kosa kata. 


\section{Penerapan Media Cerita Bergambar dalam Pembelajaran} Bahasa Arab

Langkah-langkah penerapan media cerita bergambar dalam pembelajaran bahasa arab sebagai berikut:

a. Merumuskan tujuan (kompetensi dasar yang ingin dicapai) dengan memanfaatkan media cerita bergambar.

b. Persiapan guru. Pada fase ini guru memilih dan menetapkan media cerita bergambar sebagai alat bantu yang akan dimanfaatkan guna mencapai tujuan pembelajaran.

c. Persipan kelas. Pada fase ini siswa atau kelas harus mempunyai persiapan, sebelum mereka menerima pelajaran dengan menggunakan media cerita bergambar. Guru harus dapat memotivasi mereka agar dapat menilai, menganalisis, menghayati pembelajaran dengan menggunakan media cerita bergambar dalam pembelajaran.

d. Langkah penyajian pelajaran dan pemanfaatan media cerita bergambar. Pada fase ini penyajian bahan pelajaran dengan memanfaatkan media cerita bergambar. Keahlian guru dituntut di sini. Media diperbantukan oleh guru untuk membantu tugasnya menjelaskan bahan/materi pembelajaran.

e. Langkah kegiatan siswa. Pada fase ini siswa belajar dengan memanfaatkan media cerita bergambar yang disiapkan guru. Dengan pemanfaatan media cerita bergambar ini, siswa mencoba memahami isi dari cerita bergambar tersebut 
dengan bimbingan guru.

f. Langkah evaluasi pembelajaran. Pada langkah ini kegiatan belajar dievaluasi, sampai sejauh mana kompetensi pembelajaran dapat tercapai, yang sekaligus mengetahui sejauh mana pengaruh media cerita bergambar sebagai alat bantu dapat menunjang keberhasilan proses pembelajaran. Hasil evaluasi dijadikan dasar atau bahan untuk proses pembelajaran berikutnya.

Contoh materi cerita bergambar dalam pelajaran qira'ah:

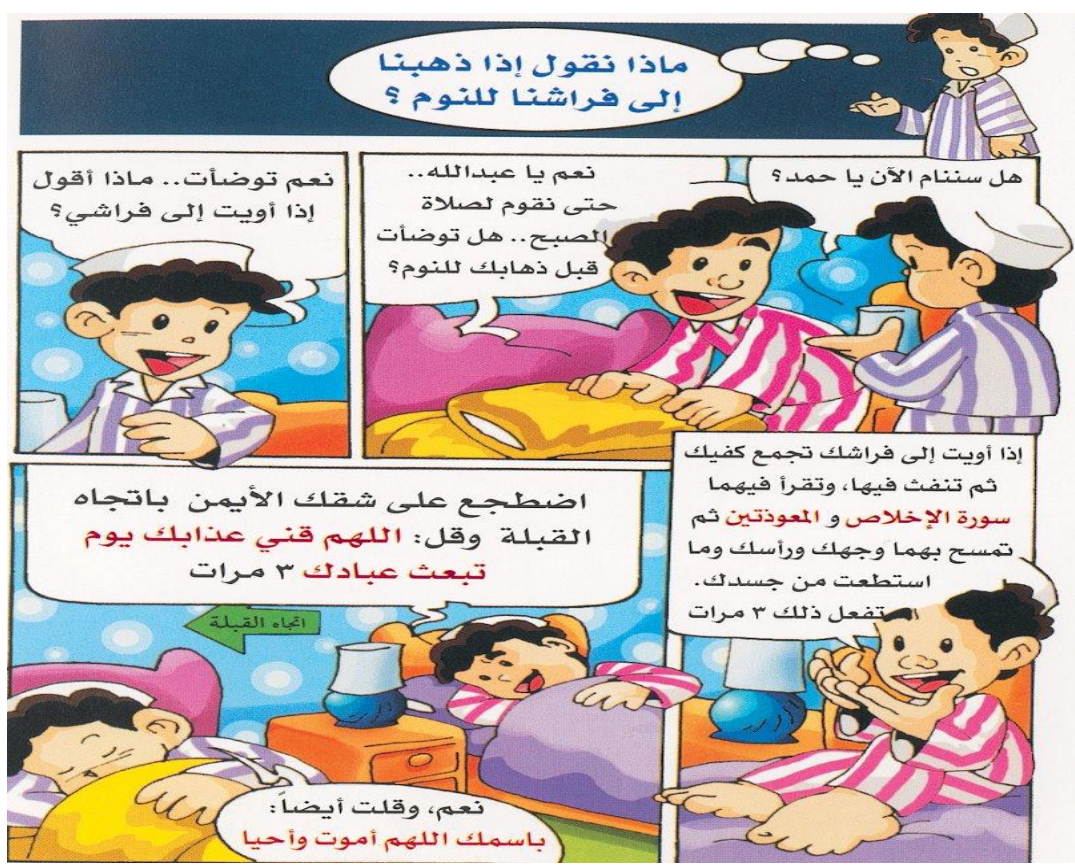




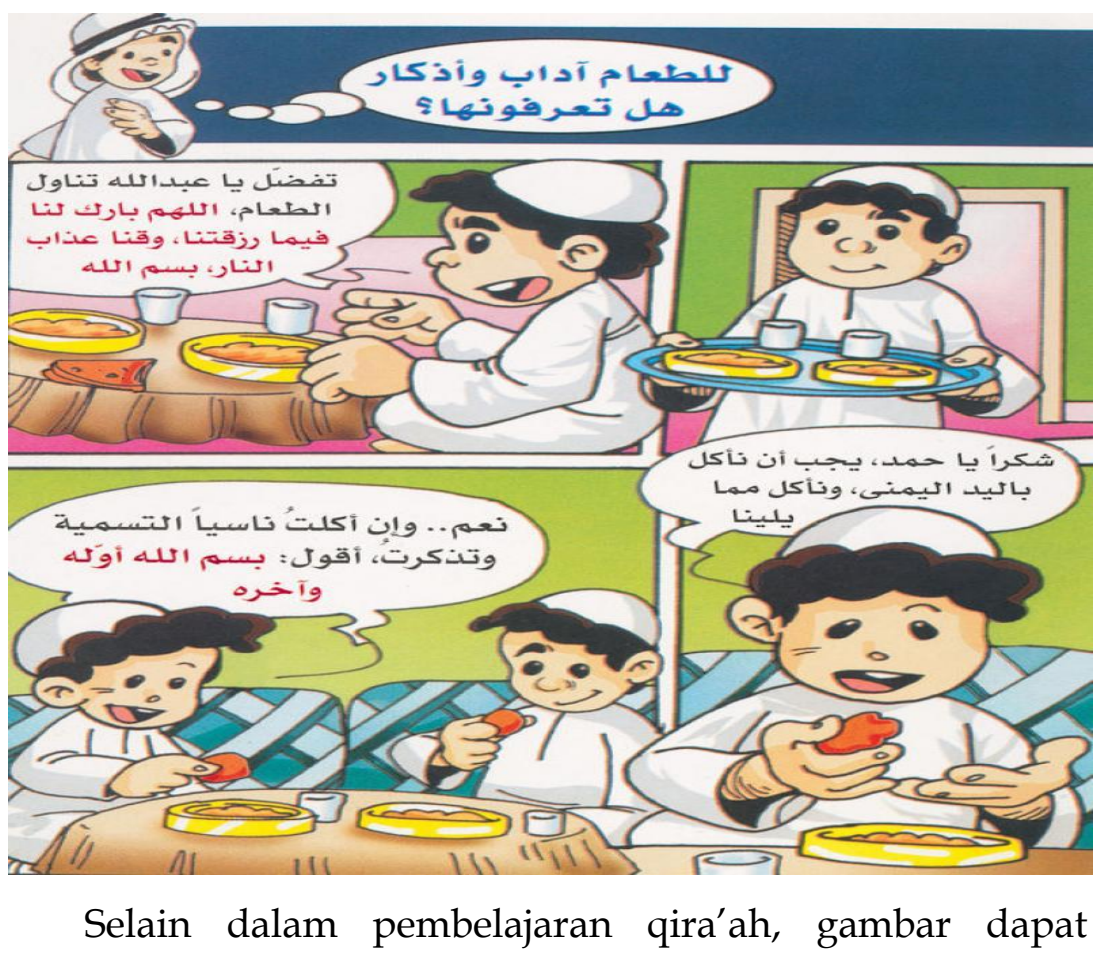
membantu pembelajar dalam memahami arti dari kosa kata secara langsung dan dengan perantara gambar maka kosa kata dapat diingat dengan mudah. Berikut contohnya: 

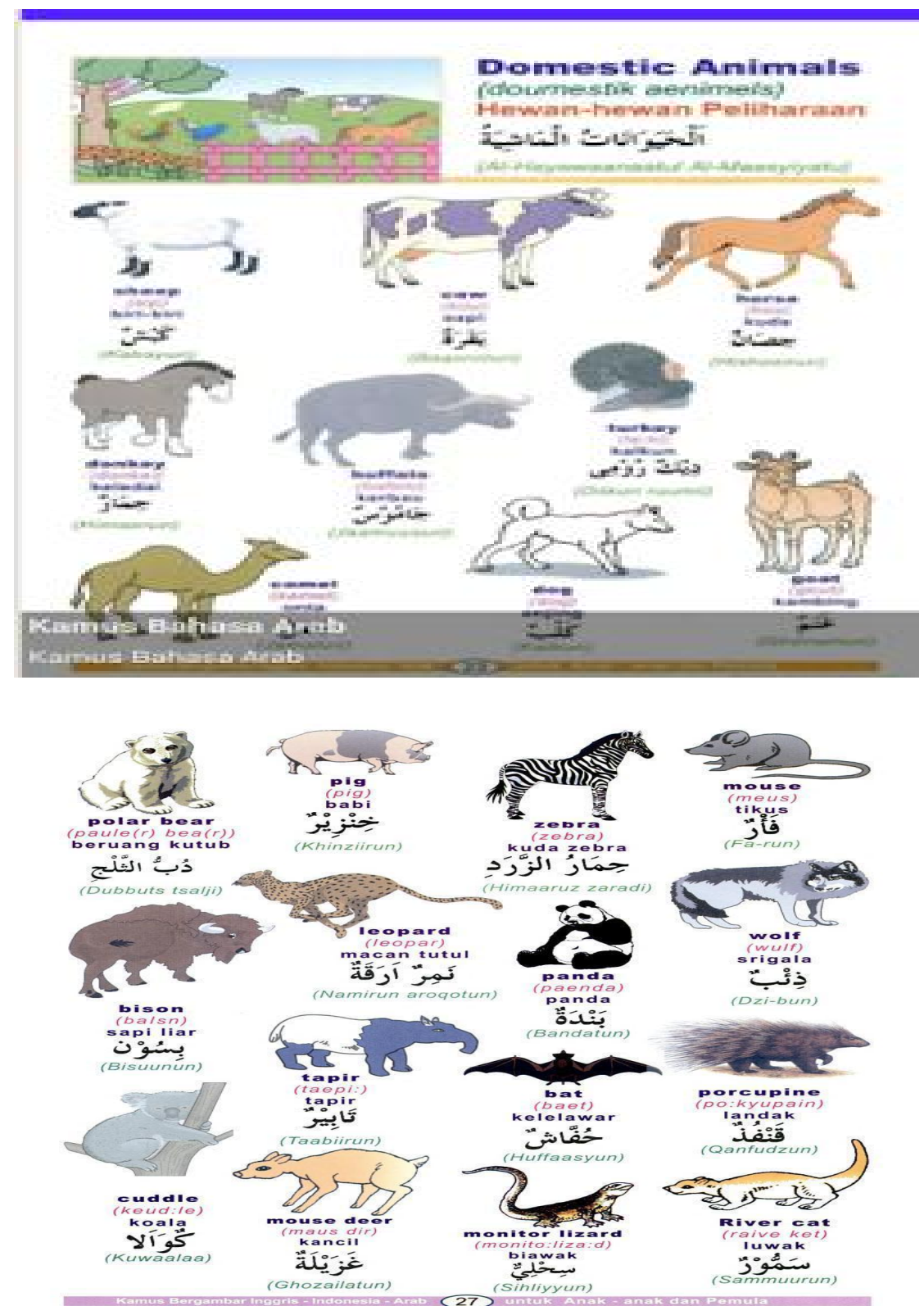

Dalam penyampaian materi dengan gambar, sebaiknya pengajar memodifikasi strategi penyampaiannya, agar media gambar yang digunakan tidak bernilai kosong. Media gambar 
dapat dijadikan sebagai sarana materi utama, dan dimodifikasi seperti permainan teka-teki menggunakan gambar, agar pembelajaran lebih melibatkan pembelajar menjadi aktif dan proses pembelajaran menjadi menyenangkan. Selain teka-teki juga dapat dimodifikasi dengan permainan monopoli, atau ular tangga. Sehingga akan ada nuansa hidup saat proses belajar mengajar.

Hal tersebut dilakukan guna meminimalisasi kekurangan dari penggunaan media gambar dalam proses belajar mengajar. Dengan adanya modifikasi dan gabungan strategi aktif diharapkan materi yang disampaikan dapat diterima dengan baik oleh pembelajar.

Setelah penyampaian materi selesai, maka evaluasi individu atau kelompok dapat dilakukan dengan segera. Seperti tanya jawab, atau kuis siapa cepat dia dapat. Evaluasi kelompok dapat berupa mencocokkan gambar dengan benar pada kosa kata yang dimaksud, cara tersebut dapat menggunakan kertas flanel besar agar pembelajar dapat berdiskusi dengan leluasa dan peran aktif masing-masing anggota kelompok tidak terhalang.

\section{Kelebihandan Kekurangan Media Gambar}

\section{a. Kelebihan Media Gambar}

Sudjana dan Rivai (2002:49) mengungkapkan beberapa kelebihan media gambar sebagai berikut:

1) Konkrit, lebih realistis dan menunjukkan pokok masalah 
atau pesan yangakan dikomunikasikan bila dibandingkan media verbal.

2) Dapat mengatasi batasan ruang dan waktu

3) Dapat mengatasi keterbatasan indera

4) Dapat memperjelas suatu masalah yang kompleks

5) Murah harganya dan mudah diperoleh.

Menurut Daryanto (2011: 100) kelebihan media gambar sebagai berikut ${ }^{31}$ :

1) Mudah dimanfaatkan di dalam kegiatan belajar mengajar karena praktis tanpa memerlukan perlengkapan apa-apa.

2) Harganya relatif murah dari pada jenis-jenis media pengajaran lainnya.

3) Gambar dapat dipergunakan dalam banyak hal, untuk berbagai jenjang pengajaran dan berbagai disiplin ilmu.

4) Gambar dapat menerjemahkan konsep atau gagasan yang abstrak menjadi lebih realistik.

Media gambar mempunyai keunggulan yang di antaranya sudah umum digunakan, mudah dimengerti, dapat dinikmati, mudah dan murah didapat atau dibuat, dan banyak memberikan penjelasan daripada menggunakan media verbal. Media gambar atau foto mampu memberikan detail dalam bentuk gambar apa adanya, sehingga anak didik mampu untuk mengingatnya dengan lebih baik dibandingkan dengan metode verbal. Selain itu media Sejahtera.

31Daryanto. 2011. Media Pembelajaran. Bandung: PT. Sarana Tutorial Nurani 
gambar juga bisa memecahkan masalah yang ada dalam media oral/verbal, yakni dalam hal keterbatasan daya ingat dalam bercerita atau menjelaskan sesuatu ${ }^{32}$.

Dari pemaparan diatas dapat diambil kesimpulan bahwa kelebihan media gambar diantaranya: tidak dibatasi ruang dan waktu, biaya lebih murah, secara visual menarik perhatian, memberikan detail apa adanya yang terjadi, mudah penggunaannya, dapat digunakan diberbagai macam materi, tanpa dibatasi usia pembelajar.

\section{b. Kekurangan Media Gambar}

Menurut Daryanto (2011: 101) kekurangan media gambar antara lain:

1) Beberapa gambarnya sudah cukup memadai, tetapi tidak cukup besar ukurannya jika digunakan untuk tujuan pengajaran kelompok besar, kecuali jika diproyeksikan melalui proyektor.

2) Gambar adalah berdimensi dua sehingga sukar untuk melukiskan bentuk sebenarnya yang berdimensi tiga.

3) Gambar tetap tidak memperlihatkan gerak seperti halnya gambar hidup.

Menurut Hamalik (1982:84) kelemahan media gambar yaitu penggunaan media gambar akan tidak efektif lagi, apabila terlalu sering digunakan dalam satu waktu tertentu. Press),64-65.

32 Dina Indriana, 2011, ragam alat bantu media pengajaran(Jogjakarta :Diva 
Dari penjelasan diatas dapat disimpulkan bahwa kekurangan media gambar adalah: tidak dapat digunakan dalam kelompok besar kecuali adanya alat pembesar tampilan gambar, dimensi gambar berpengaruh dalam menjelaskan keadaan yang ditersirat, jika gambar merupakan gambar diam dapat membuat pembelajar jenuh, dan jika media gambar tersebut digunakan berulang maka tidak akan efektif lagi digunakan.

\section{c. Tips Memilih Media}

Untuk mendapatkan kualitas media pembelajaran yang baik agar dapat memberikan pengaruh yang signifikan dalam proses belajar mengajar, maka diperlukan pemilihan dan perencanaan penggunaan media pembelajaran yang baik dan tepat. Pemilihan media pembelajaran yang tepat ini menjadikan media pembelajaran efektif digunakan dan tidak sia-sia jika diterapkan.

Arsyadmenjelaskan bahwa kriteria pemilihan media bersumber dari konsep bahwa media pembelajaran merupakan bagian dari sistem instruksional secara keseluruhan. Maka beberapa kriteria yang perlu diperhatikan dalam pemilihan media pembelajaran yang baik adalah sebagai berikut ${ }^{33}$ :

33 Arsyad, Azhar. 2013. Media Pembelajaran. Jakarta: Rajawali Press, hlm. 74 
1) Sesuai Dengan Tujuan

Media pembelajaran harus dipilih berdasarkan tujuan instruksional dimana akan lebih baik jika mengacu setidaknya dua dari tiga ranah kognitif, afektif dan psikomotorik. Hal ini bertujuan agar media pembelajaran sesuai dengan arahan dan tidak melenceng dari tujuan. Media pembelajaran juga bukan hanya mampu mempengaruhi aspek intelegensi siswa, namun juga aspek lain yaitu sikap dan perbuatan.

2) Tepat Mendukung Materi yang Bersifat Fakta, Konsep, Prinsip, dan Generalisasi

Tidak semua materi dapat disajikan secara gamblang melalui media pembelajaran, terkadang harus disajikan dalam konsep atau simbol atau sesuatu yang lebih umum baru kemudian disertakan penjelasan. Ini memerlukan proses dan keterampilan khusus dari siswa untuk memahami hingga menganalisis materi yang disajikan. Media pembelajaran yang dipilih hendaknya mampu diselaraskan menurut kemampuan dan kebutuhan siswa dalam mendalami isi materi.

3) Praktis, Luwes, dan Bertahan

Media pembelajaran yang dipilih tidak harus mahal dan selalu berbasis teknologi. Pemanfaatan lingkungan dan sesuatu yang sederhana namun secara tepat guna akan lebih efektif dibandingkan media 
pembelajaran yang mahal dan rumit. Simpel dan mudah dalam penggunaan, harga terjangkau dan dapat bertahan lama serta dapat digunakan secara terus menerus patut menjadi salah satu pertimbangan utama dalam memilih media pembelajaran.

4) Mampu dan Terampil Menggunakan

Apapun media yang dipilih, guru harus mampu menggunakan media tersebut. Nilai dan manfaat media pembelajaran sangat ditentukan oleh bagaimana keterampilan guru menggunakan media pembelajaran tersebut. Keterampilan penggunaan media pembelajaran ini juga nantinya dapat diturunkan kepada siswa sehingga siswa juga mampu terampil menggunakan media pembelajaran yang dipilih.

5) Pengelompokkan Sasaran

Siswa terdiri dari banyak kelompok belajar yang heterogen. Antara kelompok satu dengan yang lain tentu tidak akan sama. Untuk itu pemilihan media pembelajaran tidak dapat disama ratakan, memang untuk media pembelajaran tertentu yang bersifat universal masih dapat digunakan, namun untuk yang lebih khusus masing-masing kelompok belajar harus mempertimbangkan pemilihan media pembelajaran untuk masing-masing kelompok. 
Hal yang perlu diperhatikan mengenai kelompok belajar siswa sebagai sasaran ini misalnya besar kecil kelompok yang bisa digolongkan menjadi 4 yaitu kelompok besar, kelompok sedang, kelompok kecil, dan perorangan. Latar belakang secara umum tiap kelompok perlu diperhatikan seperti latar belakang ekonomi, sosial, budaya dan lain-lain. Kemampuan belajar masing-masing siswa dalam kelompok juga wajib diperhatikan untuk memilih mana media pembelajaran yang tepat untuk dipilih.

6) Mutu Teknis

Pemilihan media yang akan digunakan harus memenuhi persyaratan teknis tertentu. Guru tidak bisa asal begitu saja menentukan media pembelajaran meskipun sudah memenuhi kriteria sebelumnya. Tiap produk yang dijadikan media pembelajaran tentu memiliki standar tertentu agar produk tersebut layak digunakan. Jika produk tersebut belum memiliki standar khusus guru harus mampu menentukan standar untuk produk tersebut agar dapat digunakan untuk media pembelajaran.

Pemilihan media pembelajaran yang akan digunakan dalam pembelajaran yang memperhatikan kriteria-kriteria tersebut akan menghasilkan atau menemukan media pembelajaran yang berkualitas dan 
sesuai atau tepat digunakan untuk masing-masing materi pembelajaran. Media pembelajaran yang dipilih juga mampudengan mudah membantu guru menyampaikan materi kepada siswa, siswa juga dapat lebih mudah menerima dan memahami materi pembelajaran dengan bantuan media pembelajaran yang sudah dipilih berdasarkan kriteria diatas.

Beberapa nilai tambah lain juga bisa didapat jika tepat dalam pemilihan media pembelajaran. Misalnya siswa mampu menambah atau meningkatkan keterampilan tertentu seperti mendengarkan dan konsetrasi. Dari segi ke-ekonomisan pemilihan media pembelajaran yang mampu digunakan berkali-kali juga sangat dapat menekan biaya atau anggaran untuk pengadaan dan produksi media pembelajaran.

Dalam memilih, menyiapkan dan merancang media belajar, fasilitator perlu menguasai beberapa hal, yaitu: jenis media, fungsi media, cara membuat, dan cara kerjanya. Dalam penggunaannya, media yang dipilih perlu memperhatikan karakteristik peserta belajarnya, terutama tingkat literasi mereka (kemampuan membacamenulis dan memahami media). Bagi seorang fasilitator, penting untuk memiliki keterampilan mengembangkan jenis media yang mudah dibuat sendiri (media by design) meskipun bukannya tidak boleh menggunakan media 
dari berbagai sumber dan memanfaatkannya untuk kegiatan pembelajaran kelompok apabila relevan atau sesuai dengan kebutuhan. Media yang bisa dipersiapkan atau dibuat secara cepat oleh fasilitator sendiri antara lain:

a) Lembar penugasan (kelompok/perorangan)

b) Lembar kasus/cerita

c) Lembar praktek (panduan praktek)

d) Skenario bermain peran (role play)/drama/fragmen

e) Permainan

f) Gambar sederhana

g) Foto-foto (dari arsip foto)

h) Transparansi (yang sudah diisi)

i) Kartu metaplan (yang sudah diisi)

j) Flipchart (yang sudah diisi)

Media yang perlu dikembangkan secara khusus dan dalam pengembangannya bisa melibatkan peserta belajar, antara lain:

a) Komik/cerita bergambar

b) Fotonovela (komik foto)

c) Poster/poster seri

d) Film video

e) Boneka/wayang (puppet-show)

f) Kaset cerita

g) Lembar balik bergambar (flipchart) 
h) "Dongeng dijital"

\section{Penutup}

Media gambar menuntut pembacanya untuk menguasai kosa kata. Media gambar dapat diterapkan untuk siapapun. Dengan media gambar pembaca akan lebih mudah memahami isi cerita. Media gambar dapat diterapkan dalam materi qira'ah, qawaid, kitabah, dan istima'. Ada beberapa kelebihan media gambar diantaranya biaya yang murah, media yang mudah diterapkan dalam pembelajaran, tidak terhalang ruang dan waktu, menarik secara visual pembelajar, dan media gambar tidak dibatasi usia pembelajarnya. Adapun kekurangannya seperti pembelajar akan bosan jika media gambarnya tidak berubah untuk beberapa materi, penjelasan secara detail tidak dapat dijelaskan oleh gambar yang biasa dan media gambar tidak cocok jika digunakan dalam kelas yang besar. 


\section{DAFTAR PUSTAKA}

Arif Sadiman, R. Rahardjo, dkk, Media Pendidikan Pengertian Pengembangan dan Pemanfaatannya, (Jakarta: PT. Raja Grafindo: 1993) hlm. 20-23

Arsyad, Azhar. 2013. Media Pembelajaran. Jakarta: Rajawali Press,

Daryanto. 2011. Media Pembelajaran. Bandung: PT. Sarana Tutorial Nurani Sejahtera.

Dina Indriana, 2011, ragam alat bantu media pengajaran(Jogjakarta :Diva Press)

Hamalik, Oemar. 1982. Media Pendidikan. Bandung: alumni/1982/Bandung

http:// karya-ilmiah.um.ac.id/index.php/pkm/index

http:/ / www.smeru.or.id/report/training/menjembatani_penelitia n_dan_kebijakan/untuk_cso/file/3547.pdf.

Imam asrori dan Moh Ahsanudin, Media pembelajaran bahasa Arab dari kartu sederhana sampai web penjelajah dunia, (Malang: Bintang Sejahtera: 2016), hlm.12

Imam Asrori dan Moh. Ahsanuddin, Media Pembelajaran Bahasa Arab dari Kartu Sederhana sampai Web Penjelajah Dunia,(Malang: Bintang Sejahtera: 2016) hlm. 24

Nana Sudjana dan Ahmad Rivai, Media Pengajaran (penggunaanya dan pembuatannya), (Bandung: CV. Sinar Baru:1991), hlm 12.

Sudjana, Nana dan Rivai Ahmad. 2002. Media Pengajaran. Bandung : Sinar Baru

1991, Media Pengajaran (penggunaanya dan pembuatannya), Bandung: CV. Sinar Baru Algensindo. 